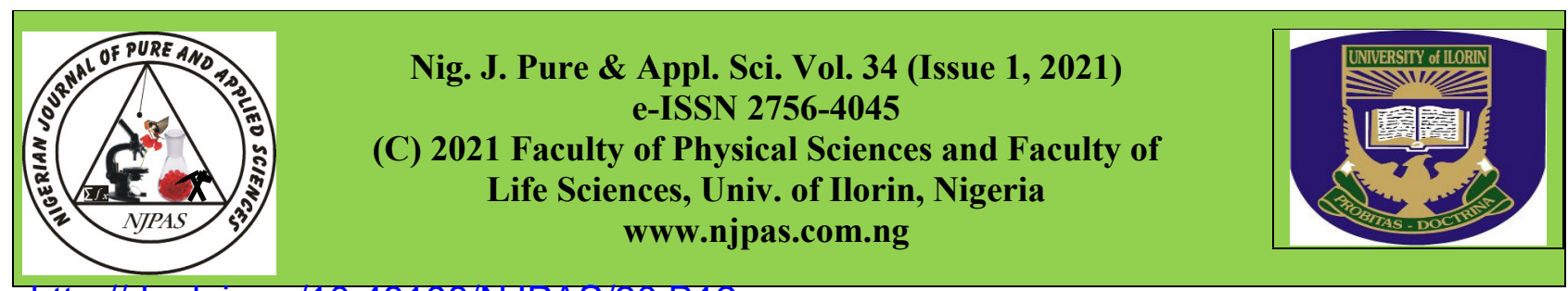

http://dx.doi.org/10.48198/NJPAS/20.B12

\title{
Comparative Anaerobic Co-Digestion Effects of Some Agricultural Biomass on Their Digestates Biochemical Properties
}

\section{${ }^{1}$ Chomini, M. Stephen, ${ }^{1}$ Kambai, Collina, ${ }^{2}$ John, W. Chinaka, ${ }^{3}$ Chomini, A. Emilia and ${ }^{4}$ Fatoke Victor.}

\author{
${ }^{1}$ Department of Forestry Technology, Federal College of Forestry, Jos, Plateau State, Nigeria. \\ ${ }^{2}$ Department of Pest Management Technology, Federal College of Forestry, Jos, Plateau State, Nigeria. \\ ${ }^{3}$ Department of Science Laboratory Technology, Federal College of Forestry, Jos, Plateau State, Nigeria. \\ ${ }^{4}$ Department of Agricultural Technology, Federal College of Forestry, Jos, Plateau State, Nigeria.
}

\section{ABSTRACT}

The huge agro-industrial biomass wastes had engendered the need for appropriate treatment technology, which could be deployed to sustainably manage and convert them to useful by-products. Consequently, the comparative anaerobic co-digestion effects of some agricultural biomass on their digestates biochemical properties were conducted. Twelve (12) replicates slurries from four mixing ratios of maize cob, poultry droppings and cow dung (1:0, 1:0, 1:0 and 1:1:1) as treatments $T_{A}, T_{B}, T_{C}$ and $T_{D}$ respectively, were separately digested in 13.6L locally fabricated batch-digester reactors, for eight weeks. Proximate and amino acids constituents were evaluated by standard procedure prior to and at post anaerobic digestion (AD). The biogas yields followed the sequence of $\mathrm{T}_{\mathrm{D}}(2200.7 \mathrm{ml} / \mathrm{kg})>\mathrm{T}_{\mathrm{B}}(2197.9 \mathrm{ml} / \mathrm{kg})>\mathrm{T}_{\mathrm{C}}(2079.0 \mathrm{ml} / \mathrm{kg})>\mathrm{T}_{\mathrm{A}}(1713.2 \mathrm{ml} / \mathrm{kg})$, showing co-substrate effects. Proximate assay depicted a decrease in crude lipid across the treatments, with $\mathrm{T}_{\mathrm{C}}$ $(86.82 \%)$ and $\mathrm{T}_{\mathrm{D}}(64.66 \%)$ as highest and lowest values. Crude fiber and nitrogen free extract had similar observation, apart from $\mathrm{T}_{\mathrm{B}}$ and $\mathrm{T}_{\mathrm{C}}$ with increased values. Percentage moisture and percentage ash contents increased across treatments. Carbon - Nitrogen ratio reduction $\left(\mathrm{C} / \mathrm{N}_{\text {Reduction }}\right)$ was in the range of 12.94 $85.79 \%$. The Percentage chemical oxygen demand reduction (CODR), followed the order of $\mathrm{T}_{\mathrm{A}}(46.81 \%)>\mathrm{T}_{\mathrm{B}}$ $(34.15)>\mathrm{T}_{\mathrm{C}}(25.81 \%)>\mathrm{T}_{\mathrm{D}}(8.00 \%)$. There was increased histidine, glycine, cystine, methionine, total nonessential amino acids (TNEAA) and total aromatic amino acids (TArAA), with decrease in aspartic acids and serine. Percentage arginine, threonine, glutamic acid, proline, alanine, isoleucine, tyrosine, total amino acids (TAA) and total essential amino acid (TEAA) decreased only in $\mathrm{T}_{\mathrm{B}}$. While, only $\mathrm{T}_{\mathrm{A}}$ had Percentage increased lysine $(25.00 \%)$, valine $(40.98 \%)$ and TArAA $(6.13 \%)$, with phenylalanine unaffected $(0.00 \%)$, Percentage leucine of $\mathrm{T}_{\mathrm{B}}(60.14 \%)$ and $\mathrm{T}_{\mathrm{D}}(23.08 \%)$ were reduced after $\mathrm{AD}$. The process had revealed the alternative waste management, energy options, and useful industrial by-products for agro-allied industries.

Keywords: Co-Digestion, Biogas, Maize Cob, Poultry Droppings, cow dung proximate analysis, amino acids Effluents

\section{Introduction}

The increase of physical volume and biomass incidental upon agricultural and biomass wastes from industries was occasioned by exponential rise in population and industrialization. These against the back drop of rising demand for and fluctuating costs of fossil fuel, have engendered the need for portable, affordable, environmentally friendly and sustainable fuels (Chomini et al., 2019a). Waste management strategies remain major front burning concerns by respective 
regional governments, due to its huge economic chunk. The bio-methanation techniques remain outstanding practicable strategies to effectively manage biodegradable municipal agricultural wastes. This derives from its numerous valued

Page | 3930 advantages including production of sustainable energy (biogas), nutrient-rich digestates(used as bio-fertilizer), production of $\mathrm{CO}_{2}, \mathrm{CFC}$ etc, and pathogenicity reduction (Babaee et al., 2013; Chomini and Joshua, 2019a; Yang et al., 2019), in addition to providing a bioremediation of toxic elements of the resultant digestates(Gupta et al., 2012; Chomini et al., 2019a).

Despite some biomethanation attempts, full exploitation of the huge biomass residues for biomethanogenesis in Nigeria is menial (Ogwus, 2019). Co-substrates anaerobic digestion involves a strategy of enhancing and optimizing biomethanation through degradation of more than one organic substrate simultaneously. It guarantees dilution of harmful substrates (Angeriz-Campoy et al., 2015), increases organic matter blend (Villamil et al., 2018), ensuring synergistic andcomplementary effects, for increased production, and enhance chemical oxygen demand (COD) and volatile solids (VS) removal efficiency, while balancing the C:N fraction thereby enhancing buffering ability (Capson-Tojo et al., 2018). It consequently reflects the metabolic status of microorganism community in digestive medium (Hallaji et al., 2019). Anaerobic mixed substrate digestion also effects process enhancement, through the improvement of carbon to nitrogen $(\mathrm{C}: \mathrm{N})$ ratio of the digestive medium. Some workers (Adebayo et al., 2015; Chomini et al., 2015), have codigested different organic wastes ranging from municipal solid wastes, animal wastes and crop residues, for biomethane production. This study therefore focused on comparative anaerobic co-digestion effectsof cow dung, poultry manure and maize cobs on the digestate biochemical properties.

\section{Materials and Methods \\ Substrate preparation}

The agricultural wastes (cow dung, poultry manure and maize cobs) collected from research unit of the Federal College Forestry, Jos, Nigeria, from were pretreated (drying, sorted, screened, pulverized and homogenized). Thereafter, mixed $(\mathrm{w} / \mathrm{w})$ in selected ratios (Table 1), parked aseptically in black polythene bags and stored below $20^{\circ} \mathrm{C}$ until use. (Chomini et al., 2015).

Table 1: Treatment description

\begin{tabular}{llc}
\hline Treatment & Description & Ratio(w/w) \\
\hline$T_{A}$ & Maize Cobs & $1: 0$ \\
$T_{B}$ & Poultry droppings & $1: 0$ \\
$T_{C}$ & Cow dung & $1: 0$ \\
$T_{D}$ & $\mathrm{~A}+\mathrm{B}+\mathrm{C}$ & $1: 1: 1$ \\
\hline
\end{tabular}

\section{Anaerobic Digestion and Biogas Evaluation}

Separate slurries of each of the treatment substrates were obtained after mixing $1000 \mathrm{~g}$ of each sample with $3000 \mathrm{ml}$ of sterile distilled water (1:3 ratio, w/v) (Grant and Marshalleck, 2008). The resultant slurries (in triplicates) were separately fed to sterilized $13.6 \mathrm{~L}$ capacity digesters. It was firmly sealed(air-tight), fitted with thermometer and gas delivery pipe, using rubber corks. The twelve (12) experimental units were arranged, using completely randomized design (CRD) under uniform temperature within the experimental chamber. They were manually shaken once daily to ensure uniform substrate condition, and keep for 8weeks digestion period. (Chomini et al., 2015). Weekly observations were made on volume of biogas produced $(\mathrm{ml} / \mathrm{kg})$, using the water displacement method, over the trial period (Chomini, 2017).

\section{Proximate assay of treatment substrates and spent slurries}

Triplicate fractions of dried, pulverized treatment samples (digested and undigested) were subjected 
to authorized procedures (AOAC, 2005), to assess proximate compositions such as moisture content (MC), crude protein (CP), crude fibre (CF), crude lipid (CL), nitrogen free extract (NFE), total ash (TA), total nitrogen (TN) and total organic carbon Page | 3931 (TOC). The chemical oxygen demand (COD) composition of the treatment substrates prior to and at post digestion were determined, using spectrophotometer DR 2800 (APHA, 2005).

\section{Assessment of Amino Acid content of Digested Samples}

The AOAC (2005) and Spackman's methods modified by Muhammad and Oloyede (2009) were adopted for analyzing the amino acid contents of both undigested and digested samples. It involved subjecting dried fractions to defattening, hydrolysis and evaporation by rotatory evaporator before loading into a Technicon Sequential Multisample (TSM) amino acid analyzer.

\section{Statistical analysis}

Data obtained were subjected to analysis of variance to determine their significant difference. Significant means were separated using least significant difference (LSD) approach.

\section{Results}

\section{Effects of Anaerobic Digestion of treatment substrates on Biogas Yields and Chemical Oxygen Demand (COD)}

There was significant $(\mathrm{P}<0.05)$ progressive rise in average biogas yields within the first six weeks of digestion (WOD). This was interrupted by sudden sharp decrease at the last two weeks of digestion. Treatment B(1:0, poultry droppings) had $93.3 \mathrm{ml} / \mathrm{kg}, 150.7 \mathrm{ml} / \mathrm{kg}$ and $262.7 \mathrm{ml} / \mathrm{kg}$ as highest weekly production for week 1-3, while treatment $\mathrm{T}_{\mathrm{D}}$ (1:1:1, maize cob : poultry droppings: cow dung) gave the best yield at weeks $4(328.3 \mathrm{ml} / \mathrm{kg})$, $5(426.0 \mathrm{ml} / \mathrm{kg}), 6(525.7 \mathrm{ml} / \mathrm{kg})$ and $7(398.7 \mathrm{ml} / \mathrm{kg})$. However, treatments $\mathrm{T}_{\mathrm{C}}$ and $\mathrm{T}_{\mathrm{D}}$ recorded $272.0 \mathrm{ml} / \mathrm{kg}$ and $128.3 \mathrm{ml} / \mathrm{kg}$ as the greatest and least values at $8^{\text {th }}$ WOD respectively (Figure 1). Cumulative yield depicted an order of treatment $\mathrm{T}_{\mathrm{D}}(2200.7 \mathrm{ml} / \mathrm{kg})>\mathrm{T}_{\mathrm{B}}(2197.9 \mathrm{ml} / \mathrm{kg})>\mathrm{T}_{\mathrm{C}}$ $(2079.0 \mathrm{ml} / \mathrm{kg})>\mathrm{T}_{\mathrm{A}}(1713.2 \mathrm{ml} / \mathrm{kg})$ (Table 4).

\section{Proximate content of treatment substrates and spent slurries}

Effects of anaerobic digestion (AD) on proximate composition revealed percentage decrease in crude lipids across the treatments which followed the order of $86.82 \%\left(\mathrm{~T}_{\mathrm{C}}\right)>77.04 \%\left(\mathrm{~T}_{\mathrm{A}}\right)>65.99 \%\left(\mathrm{~T}_{\mathrm{B}}\right)$ $>64.66 \%\left(\mathrm{~T}_{\mathrm{D}}\right)$. Similar observations were made for nitrogen free extract (NFE) and crude fiber (CF), except for treatments $T_{B}$ and $T_{C}$ which recorded percentage increases in CF $(76.03 \%)$ and NFE $(61.07 \%)$ respectively. Conversely, only treatment $\mathrm{T}_{\mathrm{B}}$ had $5.74 \%$ as percentage decrease after 8 weeks of digestion. Percentage increases in ash and moisture contents across the treatments, due to $\mathrm{AD}$, with treatments $\mathrm{T}_{\mathrm{A}}(763.60 \%)$ and $\mathrm{T}_{\mathrm{D}}$ (525.64\%), showing the highest percentage increase, while $\mathrm{T}_{\mathrm{B}}(48.06 \%)$ and $\mathrm{T}_{\mathrm{A}}(140.65 \%)$ gave the least based on anaerobic digestion respectively (Table 2). All treatments indicated outstanding reductions in carbon: nitrogen $(\mathrm{C} / \mathrm{N})$ ratios and chemical oxygen demand (COD) compositions of substrates due to $\mathrm{AD}$. The $\mathrm{C} / \mathrm{N}$ values extended from $12.94-85.79 \%$, with $\mathrm{T}_{\mathrm{B}}$ and $\mathrm{T}_{\mathrm{D}}$ having the least and highest percentage reduction, later showed an order of $46.81 \%\left(\mathrm{~T}_{\mathrm{A}}\right)$ $>34.15 \%\left(\mathrm{~T}_{\mathrm{B}}\right)>25.81 \%\left(\mathrm{~T}_{\mathrm{C}}\right)>8.00 \%\left(\mathrm{~T}_{\mathrm{D}}\right)($ table 4$)$.

\section{Anaerobic Digestion (AD) Effects on Digestates Amino Acids compositions}

There were percentage increases in histidine, glycine, cysteine, methionine, total non-essential amino acids (TNEAA) and total aromatic amino acids (TArAA) for all digestates, based on effects of $\mathrm{AD}$. These depicted $596.77 \%\left(\mathrm{~T}_{\mathrm{A}}\right)$ and $197.04\left(\mathrm{~T}_{\mathrm{B}}\right), \quad 163.64 \%\left(\mathrm{~T}_{\mathrm{C}}\right)$ and $89.47 \%\left(\mathrm{~T}_{\mathrm{D}}\right)$, $926.2 \%\left(\mathrm{~T}_{\mathrm{A}}\right)$ and $677.19 \%\left(\mathrm{~T}_{\mathrm{B}}\right), 102.78 \%\left(\mathrm{~T}_{\mathrm{D}}\right)$ and $36.96 \%\left(\mathrm{~T}_{\mathrm{B}}\right), \quad 48.47 \%\left(\mathrm{~T}_{\mathrm{C}}\right)$ and $10.47 \%\left(\mathrm{~T}_{\mathrm{B}}\right)$, and $554.41 \%\left(\mathrm{~T}_{\mathrm{A}}\right)$ and $391.26 \%\left(\mathrm{~T}_{\mathrm{B}}\right)$, as highest and lowest values respectively. Percentage aspartic 
acid and serine were notably reduced across treatments after $\mathrm{AD}$. Only treatment $\mathrm{T}_{\mathrm{B}}$ gave percentage decrease in arginine $(25.83 \%)$, threonine (6.94\%), glutamic acid (21.44\%), proline $(1.84 \%)$, alanine $(13.24 \%)$, isoleucine

Page | 3932 (16.89\%), tyrosine (19.07\%), total amino acids (TAA, 23.38\%) and total essential amino acid (TEAA, 24.44\%). Conversely, only treatment $\mathrm{T}_{\mathrm{A}}$ was positively influenced, with lysine $(25.00 \%)$, valine $(40.98 \%)$ and total aromatic amino acid (TArAA, $6.13 \%$ ). While phenylalanine fraction of $\mathrm{T}_{\mathrm{A}}$ was unaffected $(0.00 \%)$, leucine constituent of $\mathrm{T}_{\mathrm{B}}(60.14 \%)$ and $\mathrm{T}_{\mathrm{D}}(23.08 \%)$ were reduced after AD (Table 3)

Table 2: Effects of Anaerobic Digestion on Proximate Properties (\%) of the Digestates at Eight Weeks of Digestion

\begin{tabular}{cccccccc}
\hline Treatment & Condition & AS & TCL & CF & NFE & CP & MC \\
\hline \multirow{3}{*}{$\mathbf{T}_{\mathbf{A}}$} & & & & & & & \\
& BAD & 2.83 & 9.54 & 36.98 & 43.26 & 3.06 & 4.33 \\
& AAD & 24.44 & 2.19 & 22.66 & 35.42 & 11.87 & 10.42 \\
$\mathbf{T}_{\mathbf{B}}$ & \%EOD & 763.60 & -77.04 & -38.72 & -18.12 & 287.91 & 140.65 \\
& BAD & 30.69 & 6.88 & 10.68 & 31.31 & 16.19 & 4.25 \\
& AAD & 45.44 & 2.34 & 18.80 & 25.66 & 15.26 & 15.51 \\
$\mathbf{T}_{\mathbf{C}}$ & \%EOD & 48.06 & -65.99 & 76.03 & -18.05 & -5.74 & 264.94 \\
& BAD & 23.71 & 13.81 & 29.85 & 15.95 & 12.13 & 4.55 \\
& AAD & 36.97 & 1.82 & 22.16 & 25.69 & 19.19 & 22.17 \\
$\mathbf{T}_{\mathbf{D}}$ & \%EOD & 55.93 & -86.82 & -25.76 & 61.07 & 58.20 & 387.25 \\
& BAD & 19.40 & 10.30 & 25.48 & 34.01 & 6.13 & 4.68 \\
& AAD & 39.83 & 3.64 & 16.51 & 29.71 & 18.04 & 29.28 \\
& \%EOD & 105.31 & -64.66 & -35.20 & -12.64 & 194.29 & 525.64 \\
\hline
\end{tabular}

$\mathrm{BAD}=$ Before Anaerobic Digestion; $\mathrm{AAD}=\mathrm{After}$ Anaerobic Digestion; $\% \mathrm{EOD}=$ percentage Effect of Digestion; $\mathrm{AS}=\mathrm{Ash} ; \mathrm{TCL}=$ Total Crude Lipid; $\mathrm{CF}=$ Crude Fiber; $\mathrm{CP}=$ Crude Protein; $\mathrm{MC}=$ Moisture Content

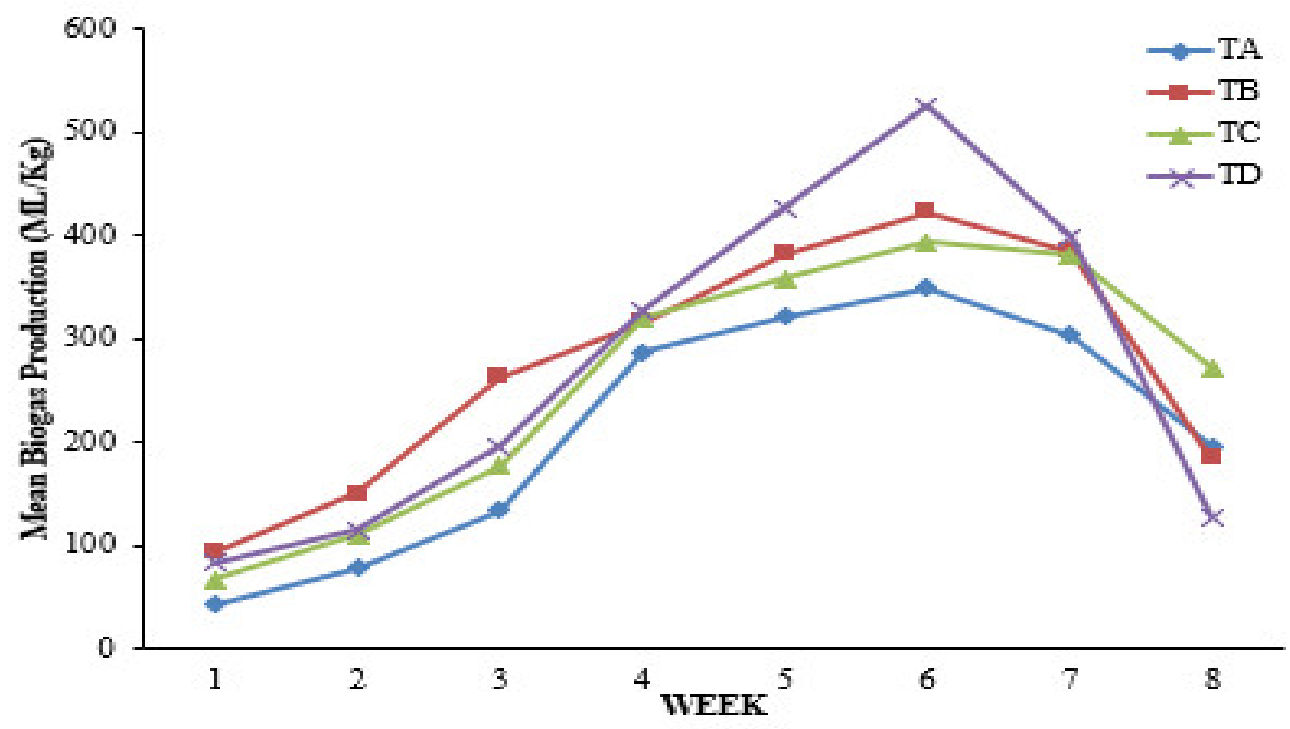

Figure 1: Mean Biogas Yield (ml/Kg) During Eight Weeks of Anaerobic Digestion 
Table 1: Effects of Anaerobic Digestion on Amino Acids Composition (\%) of the Digestates at Eight Weeks of Digestion

\begin{tabular}{|c|c|c|c|c|c|c|c|c|c|c|c|c|}
\hline Tmt & & $\mathbf{T}_{\mathbf{A}}$ & & & $\mathbf{T}_{\mathbf{B}}$ & & & $\mathbf{T}_{\mathbf{C}}$ & & & $\mathbf{T}_{\mathbf{D}}$ & \\
\hline $\mathbf{A A}$ & BAD & AAD & $\%$ Eff & BAD & AAD & $\%$ Eff & BAD & AAD & $\%$ Eff & BAD & AAD & $\%$ Eff \\
\hline Lys & 1.92 & 2.40 & 25.00 & 2.83 & 2.00 & -29.33 & 3.50 & 2.03 & -42.00 & 3.50 & 2.05 & -41.43 \\
\hline His & 0.62 & 4.32 & 596.77 & 1.35 & 4.01 & 197.04 & 1.09 & 5.27 & 383.49 & 1.06 & 4.26 & 301.89 \\
\hline Arg & 1.23 & 1.99 & 61.79 & 3.02 & 2.24 & -25.83 & 1.71 & 1.90 & 11.11 & 2.18 & 1.90 & -12.84 \\
\hline Asp & 3.35 & 2.30 & -31.34 & 4.05 & 2.26 & -44.20 & 4.02 & 2.79 & -30.60 & 3.60 & 2.70 & -25.00 \\
\hline Thr & 2.02 & 2.15 & 6.44 & 2.16 & 2.01 & -6.94 & 1.34 & 2.31 & 72.39 & 1.50 & 2.21 & 47.33 \\
\hline Ser & 1.55 & 1.09 & -29.68 & 1.93 & 1.14 & -40.93 & 1.93 & 1.25 & -35.23 & 1.64 & 1.60 & -2.44 \\
\hline Glu & 4.01 & 6.29 & 56.86 & 7.23 & 5.68 & -21.44 & 6.21 & 7.57 & 21.90 & 5.51 & 6.97 & 26.50 \\
\hline Pro & 1.20 & 2.03 & 69.17 & 2.18 & 2.14 & -1.83 & 1.17 & 2.24 & 91.45 & 1.36 & 2.24 & 64.71 \\
\hline Gly & 2.23 & 5.60 & 151.12 & 3.05 & 6.89 & 125.90 & 2.75 & 7.25 & 163.64 & 2.66 & 5.04 & 89.47 \\
\hline Ala & 2.13 & 3.19 & 49.77 & 3.55 & 3.08 & -13.24 & 2.23 & 3.34 & 49.78 & 2.60 & 3.00 & 15.38 \\
\hline Cys & 0.38 & 3.90 & 926.32 & 0.57 & 4.43 & 677.19 & 0.51 & 3.97 & 678.43 & 0.45 & 3.57 & 693.33 \\
\hline Val & 1.83 & 2.58 & 40.98 & 3.50 & 2.35 & -32.86 & 2.60 & 2.52 & -3.08 & 2.63 & 2.32 & -11.79 \\
\hline Met & 0.30 & 0.55 & 83.33 & 0.46 & 0.63 & 36.96 & 0.41 & 0.63 & 53.66 & 0.36 & 0.73 & 102.78 \\
\hline Ileu & 1.35 & 1.90 & 40.74 & 2.25 & 1.87 & -16.89 & 1.73 & 2.00 & 15.61 & 1.63 & 2.12 & 30.06 \\
\hline Leu & 1.95 & 3.00 & 53.8 & 7.25 & 2.89 & -60.14 & 2.84 & 3.20 & 12.68 & 3.90 & 3.00 & -23.08 \\
\hline Tyr & 1.08 & 1.27 & 17.59 & 2.36 & 1.91 & -19.07 & 1.08 & 1.27 & 17.59 & 1.24 & 1.59 & 28.23 \\
\hline Phe & 2.02 & 2.02 & 0.00 & 3.90 & 2.19 & -43.85 & 2.30 & 1.85 & -19.57 & 2.67 & 2.19 & -17.98 \\
\hline TAA & 29.17 & 46.58 & 59.68 & 51.64 & 47.72 & -7.59 & 37.51 & 51.39 & 37.00 & 38.49 & 47.49 & 23.38 \\
\hline TEAA & 13.24 & 22.39 & 69.11 & 26.72 & 20.19 & -24.44 & 17.52 & 21.71 & 23.92 & 19.43 & 20.78 & 6.95 \\
\hline TNEAA & 15.93 & 23.58 & 48.02 & 24.92 & 27.53 & 10.47 & 19.99 & 29.68 & 48.47 & 19.06 & 26.71 & 40.14 \\
\hline TSAA & 0.68 & 4.45 & 554.41 & 1.03 & 5.06 & 391.26 & 0.92 & 4.60 & 400.00 & 0.81 & 4.30 & 430.86 \\
\hline TArAA & 3.10 & 3.29 & 6.13 & 6.26 & 3.38 & -46.01 & 3.38 & 3.12 & -7.69 & 3.91 & 3.78 & -3.32 \\
\hline
\end{tabular}

Tmt $=$ Treatment; $\mathrm{AA}=$ amino acid $;$ Lys = Lysine; His = Histidine; Arg = Arginine; Asp =Aspartic acid; Thr $=$ Threonine; Ser $=$ Serine; Glu = Glutamic acid; Pro = Proline; Gly = Glucine ; Ala $=$ Alanine $;$ Cys $=$ Cystine $;$ Val

$=$ Valine Met $=$ Methionine; Ileu $=$ Isoleucine $;$ Leu $=$ Leucine $; \mathrm{Tyr}=$ Tyrosine $;$ Phe $=$ Phenylalanine $;$ TAA $=$

Total amino acids; TEAA $=$ Total essential amino acids; TNEAA $=$ Total non-essential amino acids; TSAA $=$ Total sulphur amino acids; TArAA $=$ Total aromatic amino acids.

Table 4: Effects of anaerobic digestion on cumulative biogas yield, \%CODR and \%C.NRed

\begin{tabular}{cccc}
\hline Treatment & $\mathbf{C B Y}(\mathbf{M l} / \mathbf{K g})$ & \%C/N & \%COD \\
\hline & & & \\
$\mathbf{T}_{\mathbf{A}}$ & 1713.2 & 81.80 & 46.81 \\
$\mathbf{T}_{\mathbf{B}}$ & 2197.9 & 12.94 & 34.15 \\
$\mathbf{T}_{\mathbf{C}}$ & 2079.0 & 29.35 & 25.81 \\
$\mathbf{T}_{\mathbf{D}}$ & 2200.7 & 85.79 & 8.00
\end{tabular}

$\mathrm{CB} \overline{\mathrm{Y}}=$ cumulative biogas yield, $\% \mathrm{CODR}=$ percentage in chemical oxygen demand reduction, $\% \mathrm{C} / \mathrm{N}_{\mathrm{Red}}=$ percentage carbon to nitrogen ratio reduction 


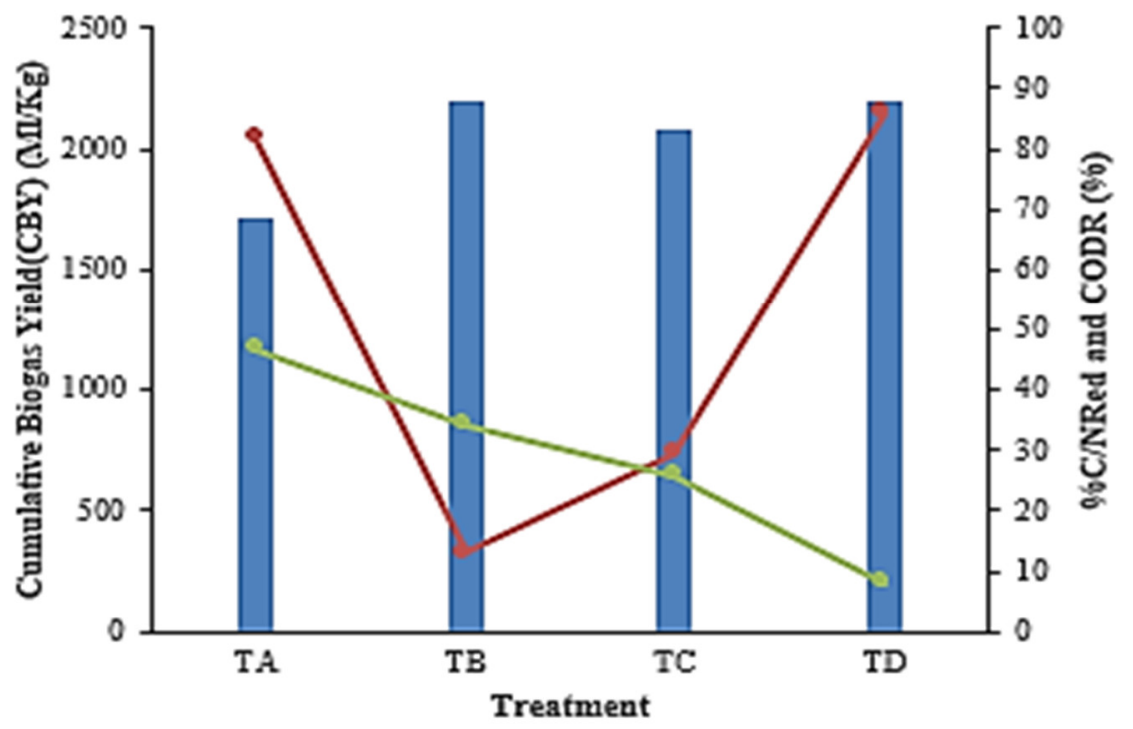

Figure 2: Effects of Chemical oxygen demand reduction (CODR) and \%Carbon/Nitrogen Reduction $\left(\% \mathrm{C} / \mathrm{N}_{\mathrm{Red}}\right)$ on Cumulative Biogas Yield $(\mathrm{CBY})(\mathrm{ml} / \mathrm{Kg})$ after 8 WOD

\section{Discussion}

Biogas yield pattern during the first 6 weeks of digestion (WOD) corroborated reports of Pramanik et al., (2019), indicating an initial increased production during the first 37day, following a decreased through the $75^{\text {th }}$ day. Hallaji et al. (2019) posited that availability of biodegradable organic matter for better microbial activity, organic loading rates (OLRs) and decreasing hydraulic retention times (HRTs) could enhance the process. Pramanik et al. (2019) and Liu et al. (2017) also attributed the observation to methanogenic activity inhibition, resulting from reactor acidification due to increased VFA. The nature of co-substrates mixing ratio were viewed to affect biogas yield significantly (Chomini et al., 2019c). The volumetric gas yield recorded its peak for $T_{D}$ (1:1:1, maize cob: poultry droppings: cow dung) with maximal weekly and cumulative yield $(2200.7 \mathrm{ml} / \mathrm{kg})$, depicting the effects of co- substrates on methanogenesis. These observations were consequent upon positive synergistic effects, more balanced nutrients, increased buffering capacity, increased bacterial due to supply of deficient nutrients during codigestion (Chomini et al., 2014).

The proximate assay depicted percentage increases in ash and moisture contents across treatments, consequent upon the biomethanation process, with treatments $\mathrm{T}_{\mathrm{A}}(763.60 \%)$ and $\mathrm{T}_{\mathrm{D}}$ (525.64\%), recording the highest percentage increase, while $\mathrm{T}_{\mathrm{B}}(48.06 \%)$ and $\mathrm{T}_{\mathrm{A}}(140.65 \%)$ gave the least effects due to $\mathrm{AD}$ (Table 3). Effects of biomethanation process gave a percentage decrease in crude lipids across treatments, following the order of $86.82 \%\left(\mathrm{~T}_{\mathrm{C}}\right)>$ $77.04 \%\left(\mathrm{~T}_{\mathrm{A}}\right)>65.99 \%\left(\mathrm{~T}_{\mathrm{B}}\right)>64.66 \%\left(\mathrm{~T}_{\mathrm{D}}\right)$. Similar observations were made for crude fiber (CF) and nitrogen free extract (NFE), apart from treatments $\mathrm{T}_{\mathrm{B}}$ and $\mathrm{T}_{\mathrm{C}}$ with recorded percentage increases in CF (76.03\%) and NFE (61.07\%) 
respectively. Conversely, only treatment $\mathrm{T}_{\mathrm{B}}$ had $5.74 \%$ as $\%$ decrease after 8 weeks of digestion.

The high moisture contents (MC) where been explained to enhance methanogenesis (Eze and

Page | 3935 Okonkwo, 2013), by dissolving readily degradable organic matter, especially at $60-80 \%$ moisture (Hernandez-Berriel et al., 2008). The MC promotes rate-determining hydrolysis stage during biomethanation process (Ma et al., 2013), by enhancing waste pretreatment especially decomposition of heavy lignocellulosic wastes (Kumar and Sharma, 2017). The enhanced percentage crude protein suggested that their initial values were adequately sufficient (Ofoefule and Ibeto, 2010). They also opined release of nitrogenous and non-nitrogenous fractions including microbial single cell protein (Dairo et al., 2011), bioconversion of dissolved carbohydrate fractions of the substrates to bacterial protein (Vijayan et al., 2009), in addition to enzymatic metabolism (Hassan, 2003). The observed decrease of percentage total crude lipid corroborated the reports of Chomini et al. (2019b), inclined to its metabolism, as ATP supply for growth of digesting microorganisms, resulting to terminal reduction. The content of cellulolytic microbial enzymes is a function of fungal species types, which determines the resultant percentage crude fiber fraction (Akinfemi et al. 2009). The carbohydrate metabolism and the medium energy capacity are other considerations (Adenipekun and Okunlade, 2012).

The general decrease in carbon: nitrogen $(\mathrm{C} / \mathrm{N})$ ratios in addition to chemical oxygen demand (COD) across the treatment effluents were discussed (Meegoda et al., 2018). They indicated implication of $\mathrm{C} / \mathrm{N}$ ratio in improving the activities of hydrolytic enzymes such as protease. This according to them, depends on the type of substrates, as substrates with high ratios, often yielded low methane (Meegoda et al., 2018). But when digested as mixed substrates with reduced
$\mathrm{C} / \mathrm{N}$ ratio, gave improved biogas yield (Figure 2). This explains current observation, with $T_{D}$ (1:1:1), having the greatest yield (Figure 1). Ghasimi et al. (2009), reported an excessively high $\mathrm{C}: \mathrm{N}$ ratio would increase acidity and retards methanogenesis, while the contrary would lead to ammonia poisoning.

The decreased percentage chemical oxygen demand, resulting from $\mathrm{AD}$, demonstrated an inverse relationship with cumulative biogas yields. This corroborated the findings of Hallaji et al. (2019). They attributed their findings to the slurries condition. Achma et al. (2014), posited that percentage COD removal depended on COD content utilized, substrate richness and digester's microbial load (Sumardiono et al., 2013). They related this as proportional to the yield. This was reinvigorated by present study (Figure 2), suggesting that microbial consortium acclimated very well, and consequently responsible for the degradation of organic fraction (COD and VS) of the substrates.

\section{Biodegradation Effects of Treatment Substrates on Amino Acid Contents}

The profile pattern of amino acids (AA) showed variations in contents due to microbial digestion effects. This was adduced to protease metabolism of protein (Feng et al., 2009). Liu et al. (2012), indicated that various AA residues reflect the extent or their metabolism. Some amino acids (isoleucine, glutamic acid lysine etc) are synthesized from their precursors, whose relative abundance determine their resultant concentrations. According to Burkovski (2005), the digestate AA contents depend on specific uptake by digesting microbes, metabolic rate de novo or from proteinoic amino acid precursor. This was in addition to mineral element requirements during microbial amino acid biosynthesis. Burkovski (2003), stipulated that availability of N-donor AA such as glutamine, glutamate, serine, alanine and asparagine, were 
responsible for specific AA synthesis. Netzer et al. (2004), reported that assimilation of $\mathrm{N}$ as ammonia, pyruvate or $\alpha$-ketoglutarate, necessitated AA synthesis. Furthermore, Burkovski (2005), indicated that degradation of

Page | 3936 S-amino acids like methionine and cysteine was responsible for AA synthesis. On the other hand, Lee (2005), found deamination of certain polypeptides and fermentation period as major determinant for AA production. Vijayan et al. (2009) stressed that dominant microbes in the digestive medium, would determine the resultant AA content. Moreover, fungal and bacterial rich media would produce high lysine and methionine contents respectively (Safari et al., 2012),

\section{Conclusion and Recommendations}

The effects of biomethanation indicated biogas yields in the order of $T_{D}(2200.7 \mathrm{ml} / \mathrm{kg})>T_{B}$ $(2197.9 \mathrm{ml} / \mathrm{kg})>\mathrm{T}_{\mathrm{C}}(2079.0 \mathrm{ml} / \mathrm{kg})>\mathrm{T}_{\mathrm{A}}$ $(1713.2 \mathrm{ml} / \mathrm{kg})$, showing the advantage of cosubstrate over the mono-substrates. Proximate analysis gave a decrease in crude lipid across the treatments with $\mathrm{T}_{\mathrm{C}}(86.82 \%)$ and $\mathrm{T}_{\mathrm{D}}(64.66 \%)$ as highest and lowest values. Crude fiber and NFE had similar observation, apart from $\mathrm{T}_{\mathrm{B}}(76.03 \%)$ and $\mathrm{T}_{\mathrm{C}}(61.07 \%)$ with increased values. All treatments recorded increased \%moisture and ash contents. Carbon - nitrogen ratio reduction $\left(\mathrm{C} / \mathrm{N}_{\text {Reduction }}\right)$ was in the range of $12.94-85.79 \%$. The percentage chemical oxygen demand reduction (CODR), followed the order of $\mathrm{T}_{\mathrm{A}}$ $(46.81 \%)>\mathrm{T}_{\mathrm{B}} \quad(34.15) \quad>\mathrm{T}_{\mathrm{C}} \quad(25.81 \%) \quad>\mathrm{T}_{\mathrm{D}}$ $(8.00 \%)$. The $\mathrm{AD}$ process engendered increased histidine, glycine, cystine, methione, total nonessential amino acids (TNEAA) and total aromatic amino acids (TArAA), and reduction in aspartic acids and serine for all treatments. Only $T_{B}$ gave percentage reductions in arginine, threonine, glutamic acid, proline, alanine, isoleucine, tyrosine, total amino acids (TAA) and total essential amino acid (TEAA). Conversely, only treatment $\mathrm{T}_{\mathrm{A}}$ was positively influenced, with lysine $(25.00 \%)$, valine $(40.98 \%)$ and total aromatic amino acid (TArAA, 6.13\%). While phenylalanine composition of $\mathrm{T}_{\mathrm{A}}$ was unaffected $(0.00 \%)$, percentage leucine was reduced for $\mathrm{T}_{\mathrm{B}}$ $(60.14 \%)$ and $\mathrm{T}_{\mathrm{D}}(23.08 \%)$ after $\mathrm{AD}$. Consequently, other levels of the substrates and other organic biomass be investigated, in addition to harnessing the proceeds of the current efforts as a veritable waste management strategy, while providing useful by-products for the agroallied industries.

\section{Competing interests}

Authors have declared that no competing interests exist.

\section{References}

Abd-essamad, M., Qarraey, I. and Ouatmane, A. (2019). Anaerobic Codigestion of Urban Solid Waste Fresh Leachate and Domestic Wastewaters: Biogas Production Potential and Kinetic. Environmental. Engineering Resources. 24(1): 38-44.

Achma, R. B., Ghorbel, A., Dafinov, A. and Medina, F. (2014). Anaerobic Digestion of Olive Oil Mill Wastewater Pre-Treated with Catalytic Wet Peroxide PhotoOxidation Using Copper Supported Pillared Clay Catalysts. Journal of Materials Science and Chemical Engineering, 2: 9-17.

Adebayo, A. O. Jekayinfa, S. O. and Linke, B. (2015). Effect Of Co-Digesting Pig Slurry With Maize Stalk On Biogas Production At Mesophilic Temperature. Journal of Multidisciplinary Engineering Science and Technology (JMEST). 2(8): 2295-2300.

Adenipekun, C. O. and Okunlade, O.A. (2012). Biodegradation of rattan wood and maize stovers by Pleurotusostreatus. Nature and Science, 10(5): 49-57. 
Akinfemi, A.O. Babayemi, J. and Jonathan S.G. (2009). Bioconversion of maize husk into value added ruminant feed by using whiterot fungus. Revista UDO Agrícola.9(4): 972-978.

Page | 3937

Angeriz-Campoy, R., Álvarez-Gallego, C.J., and Romero-García, L.I. (2015). Thermophilic anaerobic co-digestion of organic fraction of municipal solid waste (OFMSW) with food waste $(\mathrm{FW})$ : enhancement of biohydrogen production. Bioresources Technology. 194: 291-296.

AOAC (2005): Official Methods of Analysis, 18th ed., Association of Official Analytical Chemist, Washington, DC, 1168p.

APHA, (2005). Standard Method for Examination of Water and Wastewater. American Public Health Association, Washington, D. C.1368p.

Babaee A, Shayegan J, and Roshani A. (2013). Anaerobic slurry co-digestion of poultry manure and straw: Effect of organic loading and temperature. Journal of Environmental Health Sciences and Engineering. 11:15.

Burkovski, A. (2003). Ammonium assimilation and nitrogen control in Corynebacterium glutamicum and its relatives: an example for new regulatory mechanisms in actinomycetes. FEMS Microbiology Reviews. 27: 617-628.

Burkovski, A. (2005). Nitrogen Metabolim and Its Regulation. In Handbook of Corynebacterium glutamicum (Edited by Eggeling, L. and Bott, M CRC Press, Boca Raton.) pp. 333-350.

Capson-Tojo, G., Trably, E., Rouez, M., Crest, M., Bernet, N., Steyer, J. P., Delgenès, J.P. and Escudié, R. (2018). Cardboard proportions and total solids contents as driving factors in dry co-fermentation of food waste. Bioresources Technology. 248: 229-237.

Chomini, M.S., Ogbonna, C.I.C., Falemara, B.C. and Thlama, D.M. (2014). Comparative Effect of Co-Digestion of Some Agricultural wastes on Biogas Yield and Some Physical Parameters. Journal of Environmental Science, Toxicology and Food Technology (IOSR- JESTFT). 8(10)3: 17-21.

Chomini, M.S., Ogbonna, C.I.C., Falemara, B.C. and Micah, P. (2015). Effect of CoDigestion of Cow Dung and Poultry Manure on Biogas Yield, Proximate and Amino Acid Contents of Their Effluents eISSN: 2319-2380, p-ISSN: 2319-2372. 8 (11) I (Nov. 2015), PP 48-56 www.iosrjournals.org

Chomini, M. S. (2017). Comparative Studies on Biogas Production from some Selected Indigenous Substrates and the effects of their End-Products on Growth and Performance of Zea Mays L. (Maize) (Ph.D Thesis), Department of Plant Science and Technology, University of Jos, Nigeria. 90-94.

Chomini, M.S., Osasebor, F.O., Ameh, M., Peter, M.K. and Chomini, A.E. (2019a). Assessment of Biodegradation Effects of Agro-Wastes (Poultry Droppings And Cow Dung) On Some Physico-Chemical Properties Of Their Effluents. American Journal of Environment Studies. 2(1)1, 118.

Chomini, M. S., Ameh M., Osaseboh, O. F. and Chomini, A. E.(2019b). Effects of CoDigestion of Poultry Droppings and Maize Cobs on Biogas Yields and some Proximate Properties of their By-Products 
European Journal of Physical Sciences. 1(2)1: 1- 13.

Chomini, M. S., Ayodele, A.O., Abok ,C. and Chomini, A. E.(2019c). Biomethanation Effects of Organic Co-Substrates on Biochemical Properties of their Resultant Effluents. Journal of Forestry Research and Management. 16(3): 126-140.

Chomini, M.S. and Joshua, V.I. (2019a). Biodigestion Effects Of Cow Dung, Poultry Droppings And Maize Cobs On Microbiological And Physico-Chemical Properties Of The Effluents. American Journal of Agriculture. 2(1)1: 1 - 16.

Dairo, F. A. S.,.Aina, A. Omoyeni L. and Adegun, M. K. (2011). Ensiled Cassava Peel and Caged Layers' Manure Mixture as Energy Source in Broiler Starter Diet. Journal of Agricultural Science and Technolog. A 1: 519-524.

Dairo, F. A. S. and Egbeyemi, O. B. (2012). Response of weaner rabbits to diets containing fermented mixtures of cassava peel and dried caged layers' manure. African Journal of Agricultural Research. 7(49): 6588-6594.

Eze, J. I. and Okonkwo, T. M. (2013). Comparative study of composting and anaerobic digestion as a means of animal manure stabilization: A Case of Cow dung. International Journal of Scientific and Engineering Research. 4(6): 1820-1825.

Feng, L., Chen, Y. and Zheng, X.(2009). Enhancement of waste activated sludge protein conversion and volatile fatty acids accumulation during waste activated sludge anaerobic fermentation by carbohydrate substrate addition: the effect of $\mathrm{pH}$.Environmental Science and Technology. 43(12): 4373-80.
Ghasimi, S. M. D., Idris, A., Chuah, T. G. and Tey, B. T. (2009). The Effect of C:N:P ratio, volatile fatty acids and $\mathrm{Na}+$ levels on the performance of an anaerobic treatment of fresh leachate from municipal solid waste transfer station. African Journal of Biotechnology. 8 (18): 4572- 4581.

Grant, S. and Marshalleck, A. (2008). Energy production and pollution mitigation from Broilers Houses on poultry farms in Jamaica and Pennsylvania. International Journal for Service. Learning in Engineering. 3 (1): 41- 52.

Gupta, P.R.S, Singh, A., Sachan, A.S., Vidyarthi, and Gupta, A.(2012). A re'appriassal on intensification of biogas production. Renewable and Sustainable Energy Review. 16:4908-4916.

Hallaji, S.M., Kuroshkarim, M., and Moussavi, S.P. (2019). Enhancing methane production using anaerobic co-digestion of waste activated sludge with combined fruit waste and cheese whey. $B M C$ Biotechnology. 19(19):1-10.

Hassan, B. (2003). Fermentation of Fish Silage using Lactobacillus pentosus. Journal Nature Indonesia. 6: 11-15.

Hernandez-Berriel, M. C., Benavides, L.M., Perez, D. J. G., and Delgado, O. B., (2008). The effect of moisture regimes on the anaerobic degradation of municipal solid waste from Metepec (Mexico). Waste Management. 28: 14-20.

Kumar, A. K., and Sharma, S. (2017). Recent updates on different methods of pretreatment of lignocellulosic feedstocks: A review. Bioresources and Bioprocess. 2017.

Lee, H.S. (2005): Sulfur Metabolism and Its Regulation. In Handbook of 
Corynebacterium glutamicum (Edited by Eggeling, L. and Bott, M. CRC Press, Boca Raton.). pp. 351-376.

Liu, Y. L. M. Ma, H.H.P. Fang, T.Y. Gao, Z. X. Xu, Y. C. Wang, Z. G. Jing M., M., A. Tomócsik, and V. Orosz (2012). Digestate: A New Nutrient Source - Review, Biogas, Dr. Sunil Kumar (Ed.), InTech, pp 295310.

Liu, C., Wang, W., Anwar, N., Ma, Z., Liu, G. and Zhang, R. E. (2017). effects of Organic Loading Rate on Anaerobic Digestion of FoodWaste under Mesophilic and Thermophilic Conditions. Energy Fuels. 31: 2976-2984.

Ma, J., Frear, C., Wang, Z., Yu, L., Zhao, Q., Li, X., and Chen, S. (2013). A simple methodology for rate-limiting step determination for anaerobic digestion of complex substrates and effect of microbial community ratio. Bioresources and Technology. 134: 391-395.

Meegoda, J.N., Li, B. Patel, K and Wang, L.B. (2018). A Review of the Processes, Parameters, and Optimization of Anaerobic Digestion. International Journal of Environmental Research and Public Health. 15: 2224, 1-16.

Muhammad, N.O. and Oloyede, O.B. (2009): Protein fractions and amino acid profile of Aspergillus niger-fermented Terminalia catappa seed meal. African Journal of Microbiology Research. 3(3): 101-104.

Netzer, R., Peters-Wendisch, P., Eggeling, L., and Sahm, H. (2004): Co-metabolism of a Nongrowth Substrate: L-Serine Utilization by Corynebacterium glutamicum. Applied and Environmental Microbiology. 70: 7148-7155.
Ofoefule, A. U. and Ibeto, C. N. (2010). Effect of Chemical Treatment on Biogas Production from Bambara Nut (Vigna Subterranea) Chaff and its Blend with Some Wastes. PEA-AIT International Conference on Energy and Sustainable Development: Issues and Strategies (ESD 2010), Chiang Mai, Thailand..pp 1-8.

Ogwus, C. (2019). Biogas Utilization in Addressing West Africa's Energy Problems: Opportunities and Challenges. Journal of Biotechnology and Biochemistry (IOSRJBB). 5(4), 49-56.

Pramanik, S.K., Suja, F.B., Porhemmat, M. and Pramanik, B.K. (2019). Performance and Kinetic Model of a Single-Stage Anaerobic Digestion System Operated at Different Successive Operating Stages for the Treatment of Food Waste. Processes. 7(600): 1-16.

Safari, O., Farhangi, M., Carter, C., Yakhchali, B., Sunghul, B.M. and Sangatash, M. (2012): Study on The Effect of Solid-State Fermentation with Aspergillus niger On Anti-nutritional Factors of Canola Protein Concentrate with Aim of Using in The Diet of Rainbow Trout (Oncorhynchus Mykiss). The 1st International and the 4th National Congress on Recycling of Organic Waste in Agriculture, $26-27$ April 2012 in Isfahan, Iran.

Sumardiono, S. Syaichurrozi, I., Budiyono, S. and Sasongko, B. (2013). The Effect of $\mathrm{COD} / \mathrm{N}$ Ratios and $\mathrm{pH}$ Control to Biogas Production from Vinasse. International Journal of Biochemistry Research and Review. 3(4): 401-413.

Vijayan, H., Joseph, I. and Raj, R. P. (2009). Biotransformation of tuna waste by cofermentation into an aquafeed ingredient. Aquaculture Research. 4, 1047-1053. 
Villamil, J. A., Mohedano, A. F., Rodriguez, J. J., and de la Rubia, M. A. (2018). Valorisation of the liquid fraction from hydrothermal carbonisation of sewage sludge by anaerobic digestion. Journal of Chemical Technology and Biotechnology. 93: 450-456.
Yang, L.G.X., Jun Zhou, Z.W. and You, X. (2019). Impact of hydrothermal pretreatment on the anaerobic digestion of different solid-liquid ratio sludges and kinetic analysis. RSC $A d v$. 9, 1910419113.
Page | 3940 